\title{
Assessment of Crime and Crime Level in Kinondoni Police Regional Stations, Dar Es Salaam Tanzania \\ ${ }^{1}$ John Makuri Imori, ${ }^{2}$ William Amos Pallangyo \\ ${ }^{1}$ A Senior Police Officer - Tanzania Police Force \\ ${ }^{2}$ Senior Lecturer- Law School of Tanzania, Dar es salaam, Tanzania
}

\begin{abstract}
This article assesses the crime and crime level from Kinondoni Police regional stations. The determinants of crime are analyzed by using descriptive statistics and Multinomial Logistic Regression Model. The findings indicate seven determinants of crime. It points out that crime against property is the main category. Respondents with the following characteristics (youths, males, unemployed, with less earning, having low level of education and never married), are more likely to commit offences against person and crimes against property. The article suggests that police force has to review the effectiveness of its initiative of involving the community in policing and increase its finance, physical and human resources to match with growing population.
\end{abstract}

Keywords: crime, police force and remanded persons

\section{INTRODUCTION}

Peace and Security are key components to human life and development. Peace and security form a substantial platform for the country's social and economic achievement. The police force as state machinery is primarily responsible for the maintenance of peace and security. To enable the police force to perform its duties efficiently and effectively, the Government endorsed the Tanzania Police Force Reform Programme (TPFRP) in the year 2011. The programme had three pillars, namely; modernization, professionalism and community policing.

Despite TPFRP implementation, incidence of crimes is still not very impressive. According to UN World Crime Index (2014), the crime index in Tanzania in the year 2014 was 57.11 and in the year 2015 the crime index registered was 61.80. There is an increase in the crime index by the value 4.69 which is about 8.2 percent. The Tanzania Crime Statistics Report (2013) indicates that during the year 2013, there were 1,248,653 reported criminal offences (including traffic cases) as compared to $1,193,974$ offences in 2012 which depicts an increase of 54,682 offences equal to 4.6 percent. Specifically, the Tanzania Crime Statistics Report (2013) indicates that since 2011, major crimes have been increasing in Kinondoni police region. The crime statistics show that there were 8092 major crime incidents in 2011, 8410 in 2012, 7924 in 2013, 8095 in 2014 and 8804 in 2015.

The concept of crime has been variously defined by many scholars; however, there is no single definition which is all encompassing. Paranjape (2011), defined crime as the intention to and motive for causing injury or inability of a citizen to conform to the standards set by the society and their violations. Balthazar (2012) explained that crime has enormous negative implications for the society. Not only does crime affect society in terms of money (money spent in order to apprehend and punish criminals or to help repair damage done from criminal activity), but also in terms of personal safety and happiness.

According to UN World Crime Index (2015) the crime rate in Tanzania was about 61.80 as compared to 57.11 in 2014. This crime index is relatively low as compared to other countries in North and South America, Western Europe, Asia as well as other African countries. Despite this relative low crime index in Tanzania, the waves of crime incidents are experienced in the big cities like Dar-es-salaam, Mwanza, Arusha and Mbeya. The waves of crime are experienced also in the borders with political instability countries such as Democratic Republic of Congo and Burundi. According to Tanzania Police Force (TPF) Crime Report 2015, most of the criminal activities in these regions include 
homicide, theft, assaults, armed robberies, petty street crimes, burglary, house breaking, illicit drug trafficking, small arms and light weapons proliferation, human trafficking as well as highways' car hijacks.

Following the crime situation in the country and demand for security by the public Kinondoni district was declared by the government a Police Region in 2006. Since 2006 Kinondoni district was treated as administrative region in terms of provision of police services. The police services were cascaded in order to reduce crime incidences. However, the crime and crime level in Kinondoni police region hasincreased as pointed out by statistical report of 2015. This articleprovides further assessment on crime and crime levels in Kinondoni police region and suggest security initiatives.

\section{Methodology}

The study was conducted in Kinondoni which is the most populous district in Dar essalaam city's (2012 Tanzania Population and Housing Census). Statistically, also Kinondoni has the highest number of reported crimes in the country (Tanzania Crime Statistics Report, 2014).

\section{SAMPLing DESIGN}

A multi-stage sampling design was used for this study. In the first stage one police region namely Kinondoni was selected purposively for this study. In second stage police stations with detention facilities were also purposively selected. In the third stage the systematic sampling was used to select the required number of respondents at each police station.

\section{SAMPle Size Determination}

The total number of respondents (remanded persons) to be sampled for this study was obtained by using the following formula:

$$
n=\frac{N p q Z_{\alpha / 2}^{2}}{(N-1) e^{2}+Z_{\alpha / 2}^{2} p q}
$$

Where

$n$ = sample size (number of remanded persons)

$N=$ total number of remanded persons in Kinondoni police region.

$p=$ proportion in the target population

$q=1-p$

$e=$ predetermined margin of error

$Z_{\alpha / 2}=$ area under standard normal curve

$\alpha=$ level of significance

Since $\mathrm{N}$ is not known, then the formula used for calculating sample size was

$$
n=\frac{p q Z_{\alpha / 2}^{2}}{e^{2}}
$$

Where $\alpha=0.05, \mathrm{p}=0.5$ (for optimum sample size), $\mathrm{q}=1-\mathrm{p}=0.5, \mathrm{e}=0.05$ (Since the estimate should $Z_{\underline{\alpha}}=1.96$

be within 5\%) and ' $n$ ' is the sample size needed for the study, $\frac{\overline{2}}{2}$ is a constant coefficient (i.e. multiplier) associated with the confidence level that is being used (from a table of areas under the standard normal curve).

$$
n=\frac{0.5 \times 0.5 \times 1.96^{2}}{0.05^{2}}=384.16
$$

The above formula gave the optimum number of remanded persons to be selected for the sample in the study area as 385 . 


\section{Methods OF ANALYSIS}

Multinomial Logistic Regression Model was used to analyze crime incidents by grouping remanded persons into three categories according to the crime committed. These groups include those who commit crimes against person, crimes against property and crimes against state security and public tranquility. The Multinomial Logistic Regression Model is given below as

$$
\begin{aligned}
& P(Y=j)=\frac{e^{\beta_{j}^{\prime} x_{i}}}{1+\sum_{k=1}^{J} e^{\beta_{k k}^{\prime} x_{i}}} \quad \text { for } j=1,2, \ldots, J \\
& P(Y=0)=\frac{1}{1+\sum_{k=1}^{J} e^{\beta_{k k}^{\prime} x_{i}}}
\end{aligned}
$$

Where there are $\mathrm{J}$ outcomes, $x$ is a vector of explanatory variables, ${ }^{\beta_{j}}$ is a vector of parameters associated with outcome $\mathrm{j}$.

Estimated parameters were presented as odd ratios $\left(e^{\beta_{j}}\right)$. Parameters greater than one indicate the regression is associated with a probability of the outcome that is greater than the probability of the base case. Parameters below one indicate that the variable is causing the outcome to have a smaller probability than the base case. Understanding Crime and crime levels

Tappan (1947) has defined crime as an intentional act or omission in violation of criminal law, committed without defense or justification, and sanctioned by the laws as felony or misdemeanor. It appears, however, that the definition could conveniently be reduced to 'an act or omission in violation of criminal law,' since any defense or justification is to be found within the criminal law, and there is no question of violating the criminal law if some defense or justification is available for a particular act or omission to be intentional in order to be a crime; it could be made punishable on the basis of knowledge, recklessness or negligence or without any reference to the mental element of the wrongdoer.

\section{The FunCtionalists TheORY OF CRIMe}

Erickson (1968) Functionalists Theory of Crime describes deviance or crime as something that helps to maintain boundaries of acceptable and unacceptable behaviour. He argues that deviance or crime bolsters cohesion and solidarity of a community, promotes the stability of social life and employment. He defines a deviant as someone whose actions/identities have moved outside the margins of the group-when society holds him/her accountable for it, it reinforces boundaries. Every time society reacts to deviance it sharpens its authority and power.

\section{The Conflict Theory of Crime}

Sellin (1938) Conflict Theory of Crime asserted that deviance is caused by economic and political forces in society. Criminal law and the criminal justice system are viewed as vehicles for controlling the poor members of society. The criminal justice system serves the rich and powerful. Deviance and Crime are defined in ways that meet the needs of those who control society. Crime is a function of the extent of conflict generated by stratification, hierarchical relationships, power differentials, or the ability of some groups to dominate other groups in that society. The study also found that more males reported crime to the police as compared to females, and older people reported crime as compared to younger people. Robbery with violence, assault and theft were the most reported victimizations.

According to Mateja (2014) in his study to assess crime prevention by TPF found that about $94 \%$ of the respondents noted that Community Policing is the strongest method used by the Force to combat crime. Community policing is the functional partnership between Police Forces or services and the members of the Community in the prevention of crime. The program involves the introduction of Ward Police Officer and County Police Officer who live in their respective places, that is, wards and counties for the purpose of educating the community about how to protect themselves against criminals, to establish and strengthen police-public relationship, to settle various social disputes as well as collecting crime information timely. 


\section{FINDINGS AND DISCUSSION}

\subsection{Crime Incidents in Various Kinondoni Police Districts}

Table 1 below presents the descriptive statistics of the number of respondents for this study from four police districts, eight police wards and seven police streets in Kinondoni police region. The table shows that 198 respondents were from Kinondoni police districts $(51.4 \%)$; 100 respondents from Kimara police district $(26.0 \%)$; 37 respondents from Magomeni police district $(9.6 \%)$ and 50 respondents from Kawe police district (13\%).

Table1. Distribution of Sample Size

\begin{tabular}{|c|c|c|c|}
\hline \multirow{6}{*}{ Police District } & & Frequency & Valid Percent \\
\hline & Kinondoni & 198 & 51.4 \\
\hline & Kimara & 100 & 26.0 \\
\hline & Magomeni & 37 & 9.6 \\
\hline & Kawe & 50 & 13.0 \\
\hline & Total & 385 & 100.0 \\
\hline \multirow[t]{9}{*}{ Police wards } & Oysterbay & 78 & 20.3 \\
\hline & Kijitonyama & 120 & 31.2 \\
\hline & Kibamba & 100 & 26.0 \\
\hline & Mzimuni & 2 & .5 \\
\hline & Urafiki & 37 & 9.6 \\
\hline & Kawe & 24 & 6.2 \\
\hline & Goba & 2 & .5 \\
\hline & Wazo Hill & 22 & 5.7 \\
\hline & Total & 385 & 100.0 \\
\hline \multirow[t]{8}{*}{ Police streets } & Namanga & 78 & 20.3 \\
\hline & Kijitonyama & 120 & 31.2 \\
\hline & Mbezi Luis & 100 & 26.0 \\
\hline & Urafiki & 37 & 9.6 \\
\hline & Kanisani & 26 & 6.8 \\
\hline & Kunguru & 2 & .5 \\
\hline & Kiwandani & 22 & 5.7 \\
\hline & Total & 385 & 100.0 \\
\hline
\end{tabular}

Source: Field Data (2016)

\subsection{Characteristics of Respondents}

This part discusses the socio-economic and demographic characteristics of the respondents who were the remanded persons in police cells in all police districts in Kinondoni police region. The remanded persons are important for this case in order to determine the most types of crime committed, that is, crimes against person, crimes against property and crimes against state security and public tranquility.

Considering the category of crime committed, it can be observed in Table 2 that, out of 385 respondents covered in the study, 94 respondents $(24.4 \%)$ committed crimes against person, 162 respondents $(42.1 \%)$ committed crimes against property and 129 respondents $(33.3 \%)$ committed crimes agaist public tranquility.

Table2. Characteristics of Respondents

\begin{tabular}{|c|c|c|c|}
\hline & & Frequency & Valid Percent \\
\hline \multirow{4}{*}{$\begin{array}{l}\text { Type of } \\
\text { Crime }\end{array}$} & Crime against person & 94 & 24.4 \\
\hline & Crime against property & 162 & 42.1 \\
\hline & $\begin{array}{l}\text { Crime against State Security and Public } \\
\text { Tranquillity }\end{array}$ & 129 & 33.5 \\
\hline & Total & 385 & 100 \\
\hline \multirow[t]{3}{*}{ Sex } & Male & 237 & 61.6 \\
\hline & Female & 148 & 38.4 \\
\hline & Total & 385 & 100 \\
\hline \multirow[t]{3}{*}{ Age } & Juvenile & 18 & 4.7 \\
\hline & Youth & 257 & 67.3 \\
\hline & Adult & 98 & 25.7 \\
\hline
\end{tabular}




\begin{tabular}{|c|c|c|c|}
\hline & Elderly & 9 & 2.4 \\
\hline & Total & 382 & 100 \\
\hline \multirow[t]{8}{*}{ Education } & Nursery & 24 & 6.3 \\
\hline & Primary & 134 & 35.1 \\
\hline & Training after Primary education & 60 & 15.7 \\
\hline & Secondary & 74 & 19.4 \\
\hline & Tertiary & 37 & 9.7 \\
\hline & University & 28 & 7.3 \\
\hline & Not attended school & 25 & 6.5 \\
\hline & Total & 382 & 100 \\
\hline
\end{tabular}

Source: Field Data (2016)

When dealing with sex, findings in Table 2 showed that majority of the remandees interviewed, 237 (61.6\%) for this study were males. Females were 148 (38.4\%).On the other hand, age distributions of the respondents, as shown in Table 2 depicted that the $67.3 \%$ of youths were involving in crime activities. Also results in Table 2 showed that $25.7 \%$ of adults, 4.7 of juveniles and 2.4 of elderly people engaged into crime activities.

Additionally, data on education as shown in Table 2 indicate that remanded persons with primary education were the majority (35.1\%) engaging in criminal activities. This group was followed by those with secondary education (19.4\%), training after primary education $(15.7 \%)$, tertiary education $(9.7 \%)$, university $(7.3 \%)$, not attended to school $(6.5 \%)$ and nursery school $(6.3 \%)$.

Also Table 3 revealed that, majority $(53.7 \%)$ of never married remanded persons were engaging in criminality. It was followed by married couples $39.5 \%$, living together $3.1 \%$, widowed $2.1 \%$ and separated $1.6 \%$. Again, results in Table 3 show that the highest proportion (42.7\%) of the respondents were self employed followed by respondents who were employed by the government $(30.0 \%)$. Also, $10.4 \%$ of the respondents were paid family worker and $9.5 \%$ of respondents were farmers.

Regarding the income of respondents, as indicated in Table 3, $28 \%$ were earning 600,000-199,999 Tanzania shillings(Tshs.) monthly. Also the results show that $22.2 \%$ were earning 200,000 - 299,999 Tshs per month, $16.5 \%$ were earning 300,000 - 499,999 Tshs per month, $14.3 \%$ were earning an amount 120,000 - 199,999 Tshs per month, 8.9\% were earning an amount less than 60,000 Tshs per month, 8.3 were earning 500,000-999,999 Tshs per month and $1.0 \%$ were earning an amount 2,000,000-2,999,999 Tshs per month.

Table3. Characteristics of Respondents

\begin{tabular}{|l|l|l|l|}
\hline Characteristics of Respondents & Frequency & Valid Percent \\
\hline Marital Status & Married & 151 & 39.5 \\
\cline { 2 - 4 } & Never married & 205 & 53.7 \\
\cline { 2 - 4 } & Living together & 12 & 3.1 \\
\cline { 2 - 4 } & Widowed & 8 & 2.1 \\
\cline { 2 - 4 } & Separated & 6 & 1.6 \\
\cline { 2 - 4 } & Total & 382 & 100 \\
\hline Main economic activity & Employed & 104 & 30 \\
\cline { 2 - 4 } & Self employed & 148 & 42.7 \\
\cline { 2 - 4 } & Unpaid family worker & 26 & 7.5 \\
\cline { 2 - 4 } & Paid family worker & 36 & 10.4 \\
\cline { 2 - 4 } & Farming & 33 & 9.5 \\
\cline { 2 - 4 } & Total & 347 & 100 \\
\hline \multirow{5}{*}{ Average monthly income } & $<60,000$ & 28 & 8.9 \\
\cline { 2 - 4 } & $60,000-119,999$ & 91 & 28.9 \\
\cline { 2 - 4 } & $120,000-199,999$ & 45 & 14.3 \\
\cline { 2 - 4 } & $200,000-299,999$ & 70 & 22.2 \\
\cline { 2 - 4 } & $300,000-499,999$ & 52 & 16.5 \\
\cline { 2 - 3 } & $500,000-999,999$ & 26 & 8.3 \\
\cline { 2 - 3 } & $2,000,000-2,999,999$ & 315 & 100 \\
\cline { 2 - 3 } & Total & \\
\hline
\end{tabular}

Source: Field Data (2016) 


\subsection{Crime Reports and Crime Levels}

Considering the occurence of crimes in a given street, findings in Table 4 reveals that majority (91.8\%) agreed that crimes occur in their streets where as $8.2 \%$ submitted that crimes do not happen in their streets.

In case of the type of crime occuring in the respondent's street, accoriding to Table 4, 67.8\% agreed that theft happens in their streets, $27 \%$ admitted that robberies occur in their streets, $20.9 \%$ argued that armed robbery occurs in their streets, $19.1 \%$ agreed that homicide occurs in their areas, $7.9 \%$ accepted that snatching crimes occur in their streets, $16 \%$ supported that rapes occur in thier streets, $40.1 \%$ agreed that drug related offences occur in their streets, $26.2 \%$ agreed that motor vehicle theft happens in their areas, $49.5 \%$ responded that motor cylcle theft is dominant in their streets, 30.1 agreed that grabing related crimes occur in their streets and 30.1\% accepted that breakings happen in their streets.

Table4. Occurrence of Crimes in Streets

\begin{tabular}{|c|c|c|c|}
\hline \multicolumn{2}{|c|}{ Type of crime occurring in streets } & Frequency & Valid Percent \\
\hline \multirow[t]{3}{*}{ Crimes occurring in street } & Yes & 349 & 91.8 \\
\hline & No & 31 & 8.2 \\
\hline & Total & 380 & 100 \\
\hline \multirow[t]{3}{*}{ Theft occurs } & Yes & 259 & 67.8 \\
\hline & No & 123 & 32.2 \\
\hline & Total & 382 & 100 \\
\hline \multirow[t]{3}{*}{ Robbery occurs } & Yes & 103 & 27 \\
\hline & No & 279 & 73 \\
\hline & Total & 382 & 100 \\
\hline \multirow[t]{3}{*}{ Armed robbery occurs } & Yes & 80 & 20.9 \\
\hline & No & 302 & 79.1 \\
\hline & Total & 382 & 100 \\
\hline \multirow[t]{3}{*}{ Homicide occurs } & Yes & 73 & 19.1 \\
\hline & No & 309 & 80.9 \\
\hline & Total & 382 & 100 \\
\hline \multirow[t]{3}{*}{ Snatch occurs } & Yes & 30 & 7.9 \\
\hline & No & 352 & 92.1 \\
\hline & Total & 382 & 100 \\
\hline \multirow[t]{3}{*}{ Rape occurs } & Yes & 61 & 16 \\
\hline & No & 321 & 84 \\
\hline & Total & 382 & 100 \\
\hline \multirow[t]{3}{*}{ Drug abuse } & Yes & 153 & 40.1 \\
\hline & No & 229 & 59.9 \\
\hline & Total & 382 & 100 \\
\hline \multirow[t]{3}{*}{ Motor vehicle theft occurs } & Yes & 100 & 26.2 \\
\hline & No & 282 & 73.8 \\
\hline & Total & 382 & 100 \\
\hline \multirow[t]{3}{*}{ Motorcycle theft occurs } & Yes & 189 & 49.5 \\
\hline & No & 193 & 50.5 \\
\hline & Total & 382 & 100 \\
\hline
\end{tabular}

In Table 5, 73.8\% of respondents said that theft is low in their streets, $91.1 \%$ of the respondents agreed that robberies are low in their streets, $95.5 \%$ of the respondents accepted that armed robberies are low, $99.2 \%$ of the repondents agreed that homicide is low in the streets, $98.4 \%$ of the respondents said that snatching related crimes are low, $99.2 \%$ of respondents argued that rapes are low, $67.8 \%$ of respondents said that drug abuse is low, $94.2 \%$ of respondents said that motor vehicle theft is low, $71.5 \%$ accepted that motor cycle theft is low, $81.4 \%$ agreed that grabing related crimes are low and $93.5 \%$ of the respondents agreed that breakings related crimes are low in their streets.

Table5. Levels of Crime in Streets

\begin{tabular}{|l|l|l|l|}
\hline Crime level & Response & Frequency & Valid percent \\
\hline Rapes in a month & Low & 379 & 99.2 \\
\cline { 2 - 4 } & Medium & 3 & 0.8 \\
\cline { 2 - 4 } & High & 0 & 0 \\
\cline { 2 - 4 } & Total & 382 & 100 \\
\hline Drugs abuse & Low & 259 & 67.8 \\
\hline
\end{tabular}


Assessment of Crime and Crime Level in Kinondoni Police Regional Stations, Dar Es Salaam Tanzania

\begin{tabular}{|c|c|c|c|}
\hline & Medium & 30 & 7.9 \\
\hline & High & 93 & 24.3 \\
\hline & Total & 382 & 100 \\
\hline \multirow[t]{4}{*}{ Motor vehicle theft } & Low & 360 & 94.2 \\
\hline & Medium & 22 & 5.8 \\
\hline & High & 0 & 0 \\
\hline & Total & 382 & 100 \\
\hline \multirow[t]{4}{*}{ Motor cycle theft } & Low & 273 & 71.5 \\
\hline & medium & 105 & 27.5 \\
\hline & High & 4 & 1 \\
\hline & Total & 382 & 100 \\
\hline \multirow[t]{4}{*}{ Motor cycle theft } & Low & 311 & 81.4 \\
\hline & Medium & 60 & 15.7 \\
\hline & High & 11 & 2.9 \\
\hline & Total & 382 & 100 \\
\hline \multirow[t]{4}{*}{ House Breakings per month } & Low & 357 & 93.5 \\
\hline & Medium & 22 & 5.8 \\
\hline & High & 3 & 0.8 \\
\hline & Total & & 100 \\
\hline \multirow[t]{4}{*}{ Theft } & Low & 282 & 73.8 \\
\hline & Medium & 64 & 16.8 \\
\hline & High & 36 & 9.4 \\
\hline & Total & & 100 \\
\hline \multirow[t]{4}{*}{ Robberies } & Low & 348 & 91.1 \\
\hline & Medium & 19 & 5 \\
\hline & High & 15 & 3.9 \\
\hline & Total & 382 & 100 \\
\hline \multirow[t]{4}{*}{ Armed robberies in a month } & Low & 365 & 95.5 \\
\hline & Medium & 13 & 3.4 \\
\hline & High & 4 & 1 \\
\hline & Total & 382 & 100 \\
\hline \multirow[t]{4}{*}{ Homicides } & Low & 379 & 99.2 \\
\hline & Medium & 3 & 0.8 \\
\hline & High & 0 & 0 \\
\hline & Total & 382 & 100 \\
\hline \multirow[t]{4}{*}{ Snatching } & Low & 376 & 98.4 \\
\hline & Medium & 3 & 0.8 \\
\hline & High & 3 & 0.8 \\
\hline & Total & 382 & 100 \\
\hline
\end{tabular}

Source: Field Data (2016)

In case of levels of crime, the findings in Table 6 revealed that majority (43.4\%) of the respondents accepted that crime levels in their streets is medium while $36.9 \%$ agreed that the level of crime is high and $19.8 \%$ of the respondents said that it is low.

\subsection{Measures Taken by the Tanzania Police Force to Reduce Crime and Crime Levels}

Findings in Table 6 reveal that majority (297), which is about $82 \%$ of the respondents, accepted that crimes are reported to law enforcement agencies specifically the police force. Only $18 \%$ of the respondents argued that crime is not reported to police. However, few respondents argued that the police respond lately after they have been informed about the crime occurence.

Table6. Response of Citizens to Report Crime to Police

\begin{tabular}{|l|l|l|l|}
\hline & Response & Frequency & Valid Percent \\
\hline Citizens report crime & Yes & 297 & 82.0 \\
\hline & No & 65 & 18.0 \\
\hline & Total & 362 & 100.0 \\
\hline
\end{tabular}

Source: Field Data (2016)

Further, the findings in Table 7 show that majority $(260,71 \%)$ of the respondents accepted that the TPF performs its duties effectively to reduce crimes. However, 106 respondents (29\%) said that TPF does not perform its duties of reducing crimes effectively. Respondents further said that TPF has to be 
improved in terms of human resource, tools and equipment and increase funding for its optimal service delivery.

Table7. Police Force Performance to Reduce Crimes

\begin{tabular}{|l|l|l|l|}
\hline & \multicolumn{1}{|c|}{ Response } & Frequency & Valid Percent \\
\hline \multirow{2}{*}{$\begin{array}{l}\text { Police force } \\
\text { effectiveness }\end{array}$} & Yes & 260 & 71.0 \\
\cline { 2 - 4 } & No & 106 & 29.0 \\
\cline { 2 - 4 } & Total & 366 & 100.0 \\
\hline
\end{tabular}

Source: Field Data (2016)

Moreover, the findings in Table 8 indicate that about $45 \%$ of the respondents noted that Community Policing is one of the measures taken by TPF to combat crime. Community policing is the functional cooperation or partnership between TPF and members of the community in the prevention and combating crimes. Since its establishment in 2006, it had shown remarkable achievements including the introduction of Ward Police Officers, Divisional Police Officers as well as formation of neighbourhood watch groups. The police officers at the ward and division levels have roles of educating the community on means of preventing and combating crimes.

Additionally, about $23 \%$ of the respondents said that Police Patrols and Operations is among the measures used by TPF to reduce crimes. Through operations and patrols police can effect arrests, interfere with criminal plans, collect intelligence as well as increasing their visibility. These operations and patols are effective tools for deterring crimes.

About 6\% of the respondents observed that the use of Police Call Centre is a measure taken by TPF to reduce crimes. The Call Centre has free toll numbers which are 111 and 112 to enable citizens to report crime to police.

Further, about $14 \%$ of the respondents said that educating the community is among the measures used by TPF to reduce crimes. The police is educating the community through mass media and other means on how to prevent and combat crimes in their respective localities. This enables citizens to develop their own local solutions to solve their local crime problems.

Table8. Measures taken by Police Force to Reduce Crimes

\begin{tabular}{|l|l|l|}
\hline Measures taken by TPF & Frequency & Valid Percent \\
\hline Community Policing & 172 & 44.68 \\
\hline Patrols and Operations & 87 & 22.59 \\
\hline The Use of Call Centre & 25 & 6.49 \\
\hline Educating the Community & 54 & 14.03 \\
\hline Increased Police Visibility & 47 & 12.2 \\
\hline Total & $\mathbf{3 8 5}$ & $\mathbf{1 0 0}$ \\
\hline
\end{tabular}

Source: Field Data (2016)

\section{CONCLUSIONS AND RECOMMENDATIONS}

The general objective of this study was to assessment of crime levels in Kinondoni police region. Seven determinants of crime were observed, namely, location (of a police station), education level, marital status, monthly income, age, and sex of respondents. Main economic activity of respondents was statistically insignificant in explaining the category of crimes.

The Multinomial Logistic Regression Model results showed that, respondents with the following characteristics (youths, males, unemployed, with less earning, having low level of education and never married), were more likely to commit offences against person. The results also explained that, respondents with the following characteristics (youths, males, unemployed, with less earning, having low level of education and never married), were more likely to commit crimes against property.

Further, the results indicated that majority of the respondents accepted that TPF performs its duties effectively to prevent and combat crimes in Kinondoni police region. The study established that crime against property was the main category. Thus the law enforcement agencies, specifically the police force, have to take necessary and sufficient steps basing on the determined factors to combat these crimes. The police force has to review the effectiveness of its initiative of involving the community in policing commonly known as Community Policing. The number of police officers should be increased since the population keeps on growing. 
According to the Tanzania Population and Housing Census 2012, the population of Tanzania is $45,000,000$ people. With this large population, the number of police officers is about 42,924 . This means that one police officer is responsible to safeguard about $1,050(1: 1,050)$. The international standards require that one police officer should safeguard a maximum number of 450 people (1:450).TPF has to be provided with modern working tools and equipment taking into accounts the rapid growth of technology.TPF as state machinery primarily responsible for the maintenance of peace, order and tranquility, has to be provided, by the government, with adequate funding to enable its operations.

\section{REFERENCES}

Balthazar, K, R, 2012, Socio-Economic Determinants of Crime: A case of Texas. A Dissertation Submitted in partial fulfillment of the Requirements for the Degree of Master Degree in Economics, University of Texas, 2012.

Erikson, E, 1968, 'Identity, Youth and Crisis', New York, Norton

Mateja, M, 2014, 'Assessing Crime Prevention by Tanzania Police Force: A Case of ChamwinoDodoma'

Paranjape (2011) 'Criminology and Victimology with Penology', Central Law Publications,107 Darbhanga Castle, Allahabad

Tanzania Crime Statistics Report, 2014, Report on Major Crime Incidents for the Period of (2011 2015)

Sellini, T, 1938, 'Culture Conflict \& Crime', New York, p.47

United Nations 2014, 'World Crime Index by Country', World Crime Report for the Period of (2014 2015). 